UDC 631.362 .3

(C) 2017

\title{
Research of aerodynamic properties of seeds of olive crops
}

\author{
Ye. Aliyev, \\ Ph.D., Head of Department \\ Institute of Oilseed Crops NAAS \\ I. Shevchenko, \\ Ph.D., Docent,
}

Zaporozhye State Engineering Academy

The purpose. To determine aerodynamic properties of seeds of olive crops of grades of selection of Institute of olive crops of NAAS with the purpose to intensify processes of their purification and separation. Methods. Researches carried out in laboratory conditions with the use of practical standards in which basic methods of physical simulation and mathematical statistics are assumed. Results. Features of change of an angle of inclination of a straight line of trend of dependences of speed of soaring on geometrical parameters of seeds of olive crops that is determined by their shape. Conclusions. Dependences are received of speeds of soaring on geometrical parameters of seeds of olive crops: with increase of geometrical sizes of seeds the speed of soaring increased linearly for each crop.

Key words: seeds, olive crops, aerodynamics, speed of soaring, experimental researches, fractions.

SETTING THE PROBLEM. The physical and mechanical properties of seeds are important indicators that should be considered in their postharvest processing; practically all seeds are exposed to mechanical action: destruction, mixing, transportation, storage, etc. [1-3]. Designing and calculating of equipment for technological operations is impossible without knowledge of the properties that are processed. The aerodynamic properties of seeds need to be known for the formation of models and empirical mathematical dependencies, for the establishment of optimal and rational parameters of the working bodies used in the technological processes of purification and separation of seed material [4-5].

ANALYSIS OF RECENT STUDIES AND PUBLICATIONS. The works of many researchers are devoted to determination of properties of oilseed crops [6-11]. Data, that are known in the literature, about physicalmechanical and technological properties give a general characteristic, which is possible to use when developing of typical models of processes for cleaning and separating seeds. In order to intensify the processes of cleaning and separating of oilseed crops (flax, sunflower, mustard, saffron, rape, soybean), it is proposed to study their physical and mechanical properties.

MATERIAL AND METHODS. Geometric parameters and physical and mechanical properties determine the aerodynamics of seeds in the air flow. When the air moves through the layers of oil seeds (in the process of technological processing - cleaning, heat drying, active ventilation, etc.) seed behavior is determined by the speed of air movement. At low speeds, the seeds keep the properties of the layer, and air passes through the pores of the layer. Increasing the speed of air movement leads to the fact that the seeds begin to move relative to each other. The concentration of seeds in the layer decreases sharply, and the volume of the layer increases. There is a fluidization, then pseudo-boiling, when the resistance of the air flow becomes close in value to the weight of the bodies. The speed of the gas or air flow, at which the particles of the loose medium are in hover, is the whirling speed for this material. The speeds of oilseed crops were measured on the testing machine.

The scheme of the experimental machine is shown in Fig. 1. On bedplate 1 it is rigidly mounted the vertical frame 2 and the air blower 3 with a variable speed of rotation of the impeller (with the help of the LATR the engine speed is changed). The corrugated hose 4 connects the air blower and the vertical pipe 5 , the grid 6 is mounted on the bottom part. The air speed is measured by the cup anemometer 7 , height of rising of particles - a scale of 8 . On the grid of the vertical pipe there was a layer of seeds $3-5 \mathrm{~mm}$ thick. After turning on of the electric engine of the air blower, the rotor speed is gradually increased. Winding speed was determined by the height of the rising of the particles. When about $50 \%$ of the particles of the layer are 
raised in the tube space, indications of an anemometer are read out. It was studied various fractions of the material that were beforehand divided in size.

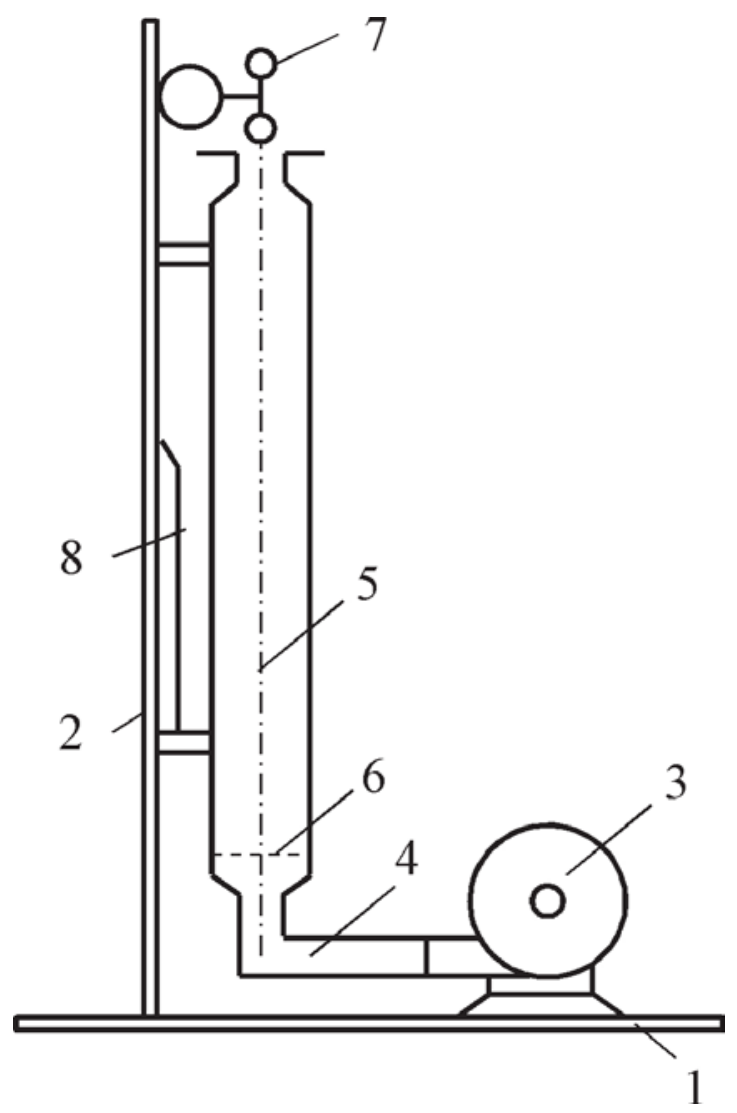

Figure 1 - Scheme of the unit for determining the rates of seed wandering: 1 - bedplate; 2 - frame; 3 - air blower; 4-corrugated hose; 5-pipe; 6-grid; 7 - cup anemometer; 8 - scale

The object of the study was seeds of selection of the Institute of Oilseeds of the National Academy of Sciences: (Flax Svetlozir, sunflower Nadioznyy, mustard Tavrichanka, camelina Prestige, rape Legion, soybeans Deni).

RESEARCH RESULTS. Figure 2 shows the trend lines that are as accurate as possible (the determination coefficient is $R^{2}=0.94-0.97$ ) describe the experimental dependences of the speed rotation on the geometric parameters of the seeds.:

flax Svetlozir

$$
V_{4}=2,4085 D_{8}+2,9388\left(R^{2}=0,9916\right) ;
$$

camelina Prestige

$$
V_{i}=3,0598 D_{1}+3,0549\left(R^{2}=0,9969\right) ;
$$

rape Legion

$$
V_{i}=2,7271 D_{i}+3,7796\left(R^{2}=0,9874\right) ;
$$

mustard Tavrichanka

$$
V_{s}=1,8798 D_{t}+3,6221\left(R^{2}=0,9975\right) ;
$$

soybeans Deni

$$
V_{i}=1,9247 D_{i}+1,0544\left(R^{2}=0,9934\right) ;
$$

sunflower Nadioznyy

$$
V_{i}=3,405 D_{i}-10,548\left(R^{2}=0,9991\right) ;
$$

where

$$
\begin{aligned}
& D_{:} \text {- effective diameter, mm; } \\
& V_{s} \text {-whirling speed, } \mathrm{m} / \mathrm{s} ;
\end{aligned}
$$


Analysis of the graphics shows that with increasing of geometrical sizes of seeds, the rate of their growth increases linearly for each oilseed crops.

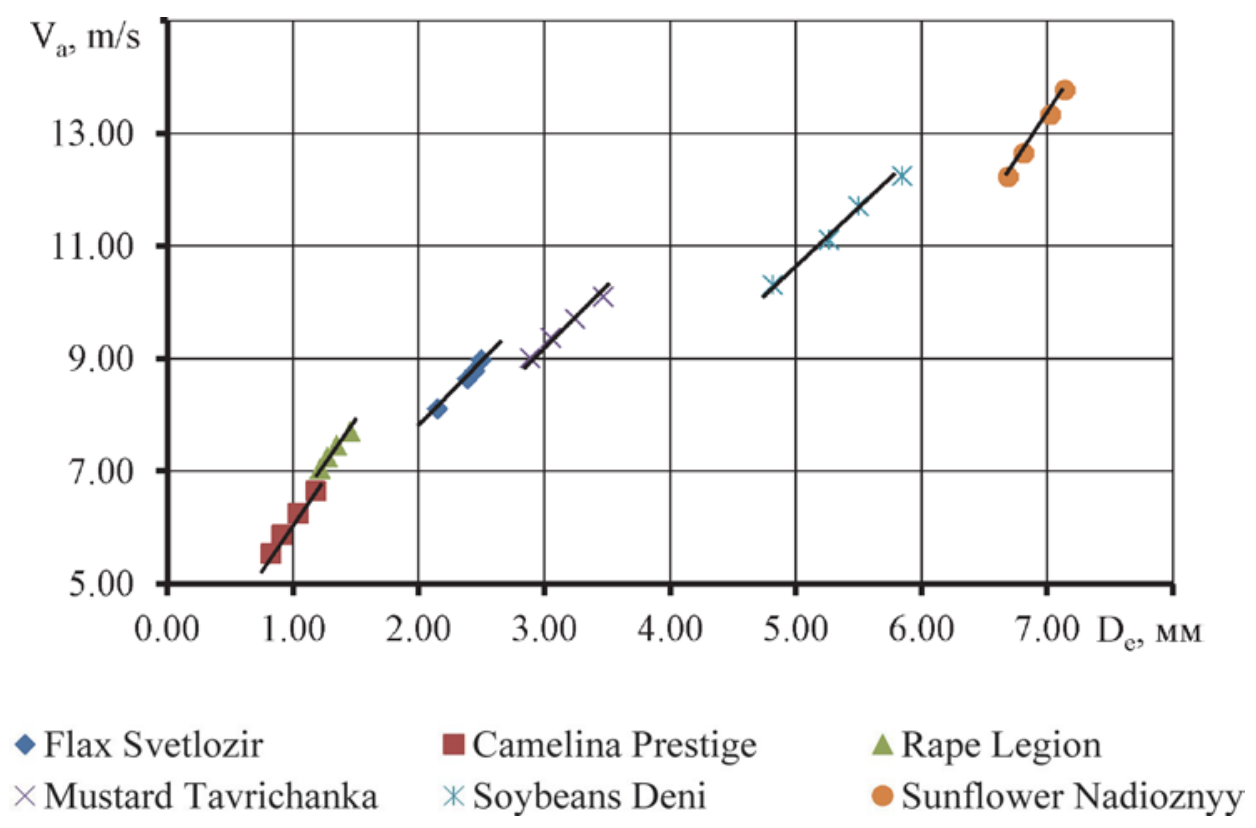

Figure 2 - Dependence of the speed of whirling on the geometric parameters of oilseeds crops

\section{CONCLUSIONS}

Aerodynamics of seeds (flax Svetlozir, sunflower Nadioznyy, mustard Tavrichanka, camelina Prestige, rape Legion, soybeans Deni) in air flow was studied for various fractions of the material that was beforehand divided in sizes. As a result of the research, the dependences of the speeds of whirling on the geometric parameters of the seeds were obtained, from which it was determined that with the increase in the geometric sizes of seeds, their whirling speed increases linearly for each oilseed crops.

\section{REFERENCES}

1. Barrozo M. The use of curvature and bias measures to discriminate among aquilibrium moisture equations for mustard seed / M. Barrozo, A. Silva, D. Oliveira // Journal of Stored Products Research. 2008. - Vol. 44 - P. 65-70.

2. Baumler E. Moisture dependent physical and compression properties of safflower seed / E. Baumler, A. Cuniberti, S. Nolasco, I. Riccobene // Journal of Food Engineering. - 2006. - Vol. 72 - P. 134-140.

3. Ghodsevali A. Studying of physical properties of sunflower in Golestan province / A. Ghodsevali, A. Vafaei // The fifth conference of agricultural machinery and mechanization. - 2008. - P. 306.

4. Gupta R.K. Aerodynamic properties of sunflower seed (Helianthus annuus L.) / R.K. Gupta, A.Gopika, R.Sharma // J. Food Eng. — Vol. 79 (3). - P. 899-904.

5. Gupta R.K. Fracture resistance of sunflower seed and kernel to compressive Loading / R.K. Gupta, S.K. Das // J. Food Eng. - 2000. — Vol. 46. - P. 1-8

6. Белобородов В.В. Основные процессы производства растительных масел / В.В. Белобородов М.: Пищевая промышленность. - 1966. - 478 с.

7. Копейковский В.М. Технология производства растительных масел / В.М. Копейковский, С.И. Данильчук и др. - М.: Легкая и пищевая промышленность, - 1982. - 416 с.

8. Пешук Л. В. Біохімія та технологія оліє-жирової сировини. Навч. посіб. / Л. В. Пешук, Т. Т. Носенко - К. : Центр учбової літератури, 2011. - 296 с.

9. Фізико-механічні властивості сировини і продукції. Навчальний посібник / С.Д. Руднєв. Кемеровський технологічний інститут харчової промисловості. — Кемерово, 2004. - 117 с. 
10. Физико-механические свойства растений, грунтов и удобрений (Методы испытаний, приборы, характеристики). - М.: Колос, 1970. - 424 с.

11. Khazaei J. Physical properties of sunflower seeds and kernels ralated to harvesting and dehulling / J. Khazaei, M. Sarmadi, J. Behzad // Lucrari Stiintifice. — 2008. — Vol. 49. 